\title{
Pancasila Clinic Model Based on Local Affairs in Village Communities (Village Case Around the Semarang State University Campus)
}

\author{
Masrukhi $^{1 *}$, Margi Wahono², Tijan $^{3}$, AT Sugeng Priyanto ${ }^{4}$, \\ 1,2,3,4 Pancasila Education and Citizenship Semarang State University City of Semarang, Indonesia \\ *Corresponding author.Email: masrukhi@mail.unnes.ac.id
}

\begin{abstract}
Local wisdom within the village community is an order of wisdom values that are locality, but are maintained from generation to generation. Its existence is a very important social capital in community empowerment. In general, people in rural areas are vulnerable to the impacts of globalization. Their limited access to information from outside their community causes shocks to occur frequently over the order of values among them. In turn, their understanding, appreciation and implementation of Pancasila in their daily lives can gradually be eroded. Many of their behaviors are no longer in accordance with Pancasila values. If this continues without any effort to strengthen the values of Pancasila, there will undoubtedly be ideological silting in their daily lives. Therefore, it is necessary to empower local wisdom as social capital, in order to strengthen the implementation of Pancasila values among them, through the development of the Pancasila Clinic.
\end{abstract}

Keywords: Pancasila Clinic, Pancasila values, villagers, Local wisdom, ideology

\section{INTRODUCTION}

Internalization of Pancasila values among rural communities is important, considering that their lives cannot be separated from the flow of globalization. There is a tendency that the dynamics of rural communities are quite high. This village community style can no longer be said to be a static society and far from changing. The information age that is currently happening will make even rural communities able to easily access all information that is happening even in the world. This condition will make the life of rural communities experience high dynamics as well, not inferior to urban communities. In other words, the flow of globalization also hits rural communities.

Conditions in rural areas, which are generally not included in the "weel educated" community, will experience serious disorientation, when the offer of globalization values is so heavy that they approach them, while they do not have sufficient references and information about the excesses of these values. This is a fact, given their very limited access to communication from the wider community.

In people's lives everywhere, values are important things that will lead to a harmonious life. Masrukhi (2014) asserts that value is interpreted as a parameter or measure that underlies humans in determining their choices. Value is a measure to determine the right and wrong of a social behavior in society. The important role of values for people's lives, in sociological studies, is to be the role of the game of a living system. With the role of the game, people will feel the need to be bound in it, obey all the signs, and pass it down from generation to generation, so that harmony is created together in everyday life. You can 
imagine what will happen, if in the life of a society there is no value parameter that is used as a reference for life together, or each community group has a different value system, which forces itself between one group and another so that its value system obeyed. Certainly a prolonged conflict will occur and there is no way out of the conflict.

The harmonization of community life in rural areas is created because of their togetherness in upholding the principles of the values of life which are believed to be true. The principles of these values are in the form of mutual cooperation, respect, respect, honesty, simplicity, mutual help, tepo saliro, and the like which have grown from generation to generation. The values of life that are inherently bodily and developing, and are firmly upheld by the village community, are basically the implementation of the values of Pancasila, in the practice of everyday life.

The value of Pancasila is the realization of the five Pancasila principles. From the precepts of the One and Only Godhead, it is determined that every Indonesian human being must be God where the manifestation is by embracing one of the religions on earth in Indonesia. The consequence is that Indonesian people acknowledge the teachings of values established by God as stated in their religious teachings. In this connection, the system of moral values adopted by a person must not conflict with the teachings of his religion and must even come from the teachings of his religion. Its manifestation is that all one's behavior, attitude, speech and way of life must be animated by the teachings of one's religion. If this is not the case, it means that the person does not recognize the precepts of Almighty Godhead.

From the principles of just and civilized Humanity, it is emphasized that Indonesian people in all their actions and ways of life must be based on human values, justice and civilization. In this state of Indonesia, oppression and raping of human rights, justice and existence are absolutely not justified.
Then from the principle of the Unity of Indonesia it is stipulated that Indonesian people must have a tendency to unite and unite. This tendency must be based on impulse from within, not coercion from without or because of certain interests. Therefore, the behavior, attitudes, and daily activities of Indonesian people must not be arbitrary, feel right for themselves by demeaning other people and so on, which can lead to divisions in Indonesian society. This last point is immoral on the basis of this third precept.

The fourth principle of Pancasila emphasizes that the rights of every citizen are the same in the Pancasila state. He must not feel more entitled to something and no one else. All rights and obligations are determined by the same laws and regulations in a fair, honest and true manner. To ensure the creation of such conditions, every action and action that concerns the interests of more than one person must be preceded by deliberation based on wisdom wisdom in the sense that it contains benefits for human life. So that there will be no complaints from people who feel that their rights as the people are not being considered by those in power, and the like.

Furthermore, the principle of social justice for all Indonesian people. The teachings of values that are derived from this precept are togetherness and tolerance among human beings. The existing prosperity should not only be enjoyed by a certain group of people, but must be enjoyed by all Indonesian people. This means that Indonesian people are required to have generous attitudes, care for others, tolerance, and the like.

All the value teachings of the five principles of Pancasila are one unity, the teachings of one precept cannot be separated. And Indonesian people must also practice it comprehensively, not partially. The value of Pancasila is the value that is derived from Pancasila both in its capacity as a view of life for the nation and as the basis of the state. The values of Pancasila also mean morality and customs according to the teachings of 
Pancasila. Every human action and action according to the definition of value above is considered moral if it is in accordance with the values and morals and norms contained in Pancasila. The measure to determine a right and good action by Indonesian people is Pancasila. In other words, Pancasila is used as a direction for all activities of life and life of Indonesian people in all fields.

The values and morals of Pancasila bind every Indonesian human being to carry it out as a moral obligation, a necessity to carry out with a sense of responsibility and discipline, for the recognition that has been given to Pancasila. These acknowledgments include Pancasila as the soul of the Indonesian nation, Pancasila as the personality of the Indonesian nation, Pancasila as the way of life of the Indonesian nation, Pancasila as the foundation of the Indonesian state, Pancasila as the source of all sources of law in Indonesia, Pancasila as the noble agreement of the Indonesian nation, Pancasila as the the ideals and goals of the Indonesian nation, Pancasila as a philosophy of life that unites the Indonesian nation.

The importance of moral values in the existence of society is also expressed by Davidson and Rees-Mog (1997: 176) as follows:

"All strong societies have a strong moral basis. Any study of history of economic development shows the close relationship between moral and economic factors. Countries and groups that achieve successful development do so partly because they have an ethic that encourages the economic virtues of self-reliance, hard work, family and social responsibility, high savings, and honesty. "

In the opinion of Davidson and Rees-Mog, it is emphasized that all solid societies have a solid moral foundation. All studies on the history of economic development show a close relationship between moral factors and economic factors. Morality will exercise control effectively through the enforcement of regulations on economic activity, and on the other hand, a strong economy will further strengthen the existence of community morality. Ellemers corroborates this thesis with the following statement:

"Another important aspect of the operation of social control has been that the sources of structural conduciveness and strain which initiated the revolution, were reduced. First of all, the new rulers succeeded in creating within the Republic a certain measure of political stability. Secondly, and strongly related to this, the also stimulated further economic growth, which implied an improvement of the overall economic situation "(2007: 101).

Countries and groups that succeed in achieving development can be this way partly because they have an ethic that encourages a spirit of independence, hard work, family and social responsibility, frugal behavior (saving), and honesty. If we look at the life of people in rural areas today, there is a crisis of values and a disorientation of value which is quite concerning. The swift flow of globalization that is so terrible befalling them, especially the younger generation, has made them very interested in the values of globalism. Meanwhile, at the same time, the values of Pancasila, which have grown from generation to generation, have become completely blurred.

Among the younger generation of rural communities, symptoms of the fragility of Pancsila values have been seen. Polite behavior, tolerance, solidarity, social care, mutual cooperation, and the like as attributes of good citizenship, are often replaced by a culture of violence. What appears to the surface is suspicion, egoism, anarchism and the like. They are also very easily provoked to commit brutality and anarchism, which in the end is detrimental to society itself at large. Therefore, one thing that is very important is the need for efforts to strengthen the Pancasila culture in people's daily lives, so that their attitudes and behavior are always animated by the Pancasila culture. With the upholding of the Pancasila culture, there will be no 
disorientation in the value of life, even though the current of globalization is so big that they hit their lives.

The Pancasila culture as meant in this case is an order of life that is animated by the values of Pancasila, and therefore the attitudes, behaviors and habits carried out by the community in daily life are always based on the values of Pancasila. The values of Pancasila which shape the culture of Pancasila are of course very broad. However, in this study a simplification is carried out, that the values in question are the values of devotion, the value of social participation, the value of democracy, the value of mutual cooperation, the value of responsibility, the value of love for the country, and the value of caring for others. The communities around the Semarang State University campus are rural communities. The life of the community nowadays, patemon, pakintelan, sukorejo, and kalisegoro (Seppasuka) always interact and communicate directly with the existence of the Unnes campus, especially with students who live in these five villages.

Symptoms that occur in rural communities regarding the excess of globalization also occur in the communities of the five villages. Moreover, the presence of the Unnes campus with so many students coming from various regions will quickly affect the lifestyle and values of the Seppasuka community. Through one of the pillars of conservation from Semarang State University, namely the pillar of cultural conservation, there are things to think about, namely how to make efforts to conserve the cultural values of the Seppasuka community so that they will stick to the principles of values that have grown from generation to generation, which are in harmony with the Pancasila values. Pancasila culture is the culture of the Indonesian people, including the culture of rural communities, in particular the urban village community in the Seppasuka neighborhood.

The Department of Politics and Citizenship thus has direct responsibility for cultural conservation efforts, in the form of conservation of the Pancasila values in community life in the five kelurahan. This is very possible given that the Department of Politics and Citizenship has a Padepokan Character laboratory, which can systematically foster the values of Pancasila among the Seppasuka community. Its visibility is very high considering the geographical location of the Seppasuka community is very close to the Unnes campus, especially the Padepokan Character Laboratory of the Politics and Citizenship Department.

This paper examines issues regarding the portrait of the implementation of Pancasila culture in the daily life of rural residents, the factors that become obstacles in implementing the cultural values of Pancasila, identifying social capital among them, and developing a Pancasila clinical model that is in accordance with people's lives in village.

\section{METHODS}

This study uses a Qualitative Research approach, which is research in which data is stated in its natural state or as it is, without being changed in the form of symbols or numbers (Brannen, 2002). This research was conducted in five urban villages around Semarang State University, namely Sekaran, Patemon, Pakintelan, Sukorejo, and Kalisegoro (Seppasuka) villages, Gunungpati District, Semarang City.

The focus in this study is a portrait of the implementation of Pancasila culture in the daily life of the Seppasuka community, which includes understanding, appreciating and cultivating the values of Pancasila. Then the factors that become obstacles in implementing the cultural values of Pancasila, include the level of community education, psychological factors, and sociological factors. While the third focus is social capital that encourages the implementation of Pancasila cultural values, including social institutions, community values, and community kinship. The fourth 
focus is the identification of the need for the Pancasila clinic.

Furthermore, the primary data sources are research informants, namely village officials, community leaders, and religious leaders in the five kelurahan that are the research locations. Meanwhile, secondary data sources are official documents, namely documents in the offices of the five kelurahan that are the research locations.

The data collection process in this study used interview techniques and documentation study. To test the validity of the data, triangulation techniques are used, namely checking the data that uses something other than the data for checking and comparison of the data (Moleong, 2000).

Meanwhile, in analyzing the data, an interactive analysis model was used, namely the form of interaction on three components; data reduction, data presentation, and data verification. This activity is carried out during the data collection process.

If the conclusion (data verification) is inadequate because of possible weaknesses in data reduction and presentation, field notes are excavated. If the latter method is not found, data collection will be carried out again to deepen the analysis.

\section{RESULT AND DISCUSSION}

Pancasila society is an idealized society. Pancasila as a national ideology, according to Latif (2015) is a static basis that unites at the same time a dynamic guiding star (leitstar), which directs the nation in achieving its goals. In such a position, Pancasila is the source of identity, personality, morality, and the direction of safety for the community, nation and state.

As the basis for morality and social, national and state direction, Pancasila has strong ontological, epistemological and axiological foundations. Each principle has a justification for its historicity, rationality, and actuality, which if it is understood, lived, believed and practiced consistently can sustain the great achievements of the nation's civilization (Latif 2015). This is the basic argument for the need for the values of
Pancasila to be actualized and contextualized in the values of Pancasila in building the desired society, both in the position of Pancasila as a way of life, personality, national ideology, and the basis of the state.

Pancasila as the nation's life view is used as a guide in the daily life of the Indonesian people, both in terms of attitude and behavior, it must always be imbued with the noble values of Pancasila. This is very important because by applying the noble values of Pancasila in everyday life, a harmonious life system between people can be realized. To be able to achieve all of this, among the community members cannot live alone, they must continue to maintain relationships in positive-constructive communication and interaction. That way, the individual's view of life can adapt to the view of life of the group in society.

Through the process of communication between residents, the process of living the values of Pancasila can occur. Living here means accepting, supporting, and committing to implement the values and norms contained in Pancasila. The process of appreciation occurs when there is dialogue, togetherness, and exemplary among residents to find solutions to problems faced together. Dialogue, togetherness, and exemplary occur when residents observe, explore, analyze, and seek and find alternative solutions to everyday problems. The intensity of community consultation within the family, neighborhood, community, and existing community communities continues to be improved. This process is expected to build people with awareness and belief in the truth and the efficacy of Pancasila values.

People with Pancasila awareness, who are able to think critically, borrow the formula used by Ennis (Amal, 2017), have the following indicators: 1) are able to formulate problem issues: looking for clear answers to every problem; 2) able to reveal the facts needed to solve the problem; 3) able to choose logical, 
relevant, and accurate arguments; 4) able to look for alternatives, seek explanations as much as possible, and take a position when there is sufficient evidence; and 5) able to determine the consequences of an alternative taken to determine a decision. Such societies are often referred to as civil society.

Perhaps the problem in cultivating Pancasila is too surplus of speech, but too minus of action. This is what Latif (2017) argues, that many people doubt the "supernatural powers" of Pancasila in the realities of everyday life. Therefore, an effort must be made to preach and mainstream exemplary stories in practicing the values of Pancasila. Such exemplary stories exist in all levels of society, including in villages / families and even within families. These exemplary stories serve as references, inspiration, and references in struggles, dialogues and debates in solving everyday problems in society.

In social service learning theory, various forms of adult role models can inspire and become a reference for the younger generation in shaping their behavior. Practices in education, based on the results of research by Lerner et al. (2001) and Warter and Grossman (2001) (in Nucci 2016), assert that there is a reciprocal transaction between students and context. According to these theorists, societies in which students work as volunteers will provide a distinctive cultural, environmental, political, and historical context. In this context, the younger generation will learn from public affairs and social issues in their community. Adults inherit the values of Pancasila in the context of community life.

The implementation of the Pancasila values of the villagers will be manifested in their ability to play a proactive role as citizens and citizens of the community, which is reflected in the order of their daily life. Village communities are people with simple patterns of thought and behavior. This simplicity is due to their limited access to information from the outside world in terms outside their life. Moreover, they are completely unfamiliar with big data in cyberspace. Therefore this is a complex implementation portrait based on the normative identity of the nation. They will show their performance as citizens who are animated in their daily lives by divine values, human values, nationality, democracy and social care.

The implementation of Pancasila values cannot be separated from three important aspects, namely an understanding of the values of Pancasila, appreciation of the values of Pancasila and ultimately the practice of Pancasila values in the daily life of rural communities. The values of Pancasila include values that derive from the first precept, in the form of belief and piety in God Almighty in accordance with each other's religions and beliefs in a civilized manner, mutual respect for choice of religion and belief and freedom to practice worship according to religion and belief. respectively, fostering a compassionate and tolerant divine spirit in intra and interreligious life by not resorting to violent methods and coercing religious beliefs on others, developing association and cooperation between followers of different religions and beliefs so that harmony is fostered living, and prioritizing religious morals as the foundation of public ethics by maintaining integrity in the integrity of the mind, words and deeds.

From the values of the second principle, Pancasila is in the form of recognizing equality, equality of rights, and equal obligations among human beings, upholding human values by respecting the basic rights of humans as individuals, as citizens, and as part of the collectivity, developing a sense of humanity and character. human character towards fellow human beings and other creatures as well as fond of carrying out humanitarian activities, dare to fight for truth and justice for the sake of human dignity, and the Indonesian nation feels itself to be part of all mankind, therefore an attitude of respect and cooperation with other nations is developed. 
Furthermore, the third principle of Pancasila covers the following values. Demonstrate a sense of belonging and love for the country and are willing to protect the entire nation and all spilled Indonesian blood, prioritizing the unity, integrity, interests and safety of the nation-state above personal or group interests, willing to sacrifice for the interests of the nation and state, proud to be the Indonesian nation with honor the potential and results of his work, as well as promoting the spirit of mutual cooperation and cross-cultural association for the sake of unity and integrity of the nation which is Bhineka Tunggal Ika.

The values of the fourth principle of Pancasila include values, including respecting the aspirations and interests of the people in politics by continuing to improve democratic systems and practices, respecting differences in views by not imposing will on others, prioritizing deliberation in making decisions concerning life together guided by wisdom and common sense in accordance with a noble conscience, with good faith and a sense of responsibility to accept and carry out the results of the deliberations, and to carry out the public's role responsibly.

Finally, the fifth principle of Pancasila, which covers the values of developing a joint business with the spirit of helping, likes to provide assistance and avoids the attitude of blackmailing others, jointly strives for economic independence and equitable progress in welfare, does not carry out economic activities that waste resources and cause harm. general welfare, and likes to work hard and appreciate the work of others.

The values of the five Pancasila are a unity that cannot be separated from one another. Because of this unity of values is the hallmark of Pancasila as the nation's view of life, the basis of the state, as well as the personality of the Indonesian nation.

Thus photographing the implementation of Pancasila values in people's lives, cannot be done partially, but rather a unity of values from the first to the fifth precept, with stages from understanding the values of Pancasila, living up to the values of Pancasila and ultimately practicing the values. -The values of Pancasila in everyday life.

The performance of the implementation of Pancasila values among village communities which is the target of research can be described as follows.

\begin{tabular}{|c|c|c|c|c|c|}
\hline No. & Realm & Sila & score & Category & $\begin{array}{l}\text { Info } \\
\text { rma } \\
\text { tion }\end{array}$ \\
\hline \multirow[t]{5}{*}{1.} & $\begin{array}{l}\text { Understa } \\
\text { nding }\end{array}$ & $\begin{array}{ll}\text { The } & \text { first } \\
\text { principle }\end{array}$ & 72.67 & High & \\
\hline & & Second precept & 63.40 & Moderate & \\
\hline & & $\begin{array}{l}\text { The third } \\
\text { precept }\end{array}$ & 50.40 & Low & \\
\hline & & $\begin{array}{ll}\text { The fourth } \\
\text { precept }\end{array}$ & 50.00 & Laceah & \\
\hline & & $\begin{array}{l}\text { The fifth } \\
\text { precept }\end{array}$ & 49.00 & Low & \\
\hline \multirow[t]{5}{*}{2.} & $\begin{array}{l}\text { Appreciat } \\
\text { ion }\end{array}$ & $\begin{array}{l}\text { The first } \\
\text { principle }\end{array}$ & 60.00 & Moderate & \\
\hline & & Second precept & 65.00 & Moderate & \\
\hline & & $\begin{array}{l}\text { The third } \\
\text { precept }\end{array}$ & 50.00 & Low & \\
\hline & & $\begin{array}{ll}\text { The fourth } \\
\text { precept }\end{array}$ & 52.60 & Low & \\
\hline & & $\begin{array}{l}\text { The } \\
\text { precept }\end{array}$ & 49.00 & Low & \\
\hline \multirow[t]{5}{*}{3.} & Practice & $\begin{array}{l}\text { The first } \\
\text { principle }\end{array}$ & 90.00 & $\begin{array}{l}\text { Very } \\
\text { high }\end{array}$ & \\
\hline & & Second precept & 86.45 & $\begin{array}{l}\text { Very } \\
\text { high }\end{array}$ & \\
\hline & & $\begin{array}{l}\text { The } \\
\text { precept }\end{array}$ & 85.00 & High & \\
\hline & & $\begin{array}{l}\text { The } \\
\text { precept }\end{array}$ & 85.00 & High & \\
\hline & & $\begin{array}{l}\text { The } \\
\text { precept }\end{array}$ & 60.00 & Moderate & \\
\hline
\end{tabular}

Note:

20 - 36 is very low

37 - 53 low

54 - 70 moderate

71 - 86 high

$87-100$ is very high

The research findings regarding the implementation of Pancasila values among village communities, as described above, show that in general their understanding of the Pancasila values is low, especially the third, fourth, and fifth sile. Only on understanding the first value has a high degree. This is reasonable considering that in general rural communities are religious societies, and the first precepts are concerned with religious life. Meanwhile, understanding of human values is moderate. This is related to the habits of 
village people who have a high level of kinship with fellow community members.

Whereas in the realm of appreciation of the values of Pancasila, the findings of the study show that the levels are moderate and low. The appreciation of the values of the first and second precepts of Pancasila is moderate, while the appreciation of the values of the third, fourth, and fifth principles is low.

The low understanding and appreciation of the village community towards the values of Pancasila is actually more due to limited access to information about Pancasila. Their busy routine with their work as farmers does not allow them to interact intensely with information surrounding Pancasila values. Likewise, the very limited social interaction, which only occurs between them fellow farmers and village communities, makes the spectrum of their conversation and discussion only limited to their daily lives.

Thus their low understanding and appreciation of the values of Pancasila is not caused by a low level of nationality, but rather due to limited access to information and social interaction networks between them. This is evidenced by the realm of implementing the values of Pancasila as revealed in this study. The table above shows that in the realm of implementing the values of Pancasila, the levels are in the very high and high categories. In the practice of the first and second precepts of precepts are very high content, and in the practice of the third, fourth, and fifth precepts. This implies that in practical life they have implemented the values of Pancasila in their daily lives. The problem then is how to strengthen the understanding and appreciation of the village community towards the values of Pancasila. These two domains are important considering that authentic practice of a value will occur when it is based on a good understanding and appreciation of the value system.

Efforts to build an understanding and appreciation of the value of Pancasila among the village community, of course, must be done by following the rhythm of the life of the village community, most of whom are busy with their work as farmers. So taking coaching time at night is an alternative that can be considered. In addition, this activity must be carried out in the vicinity of the community they live in. Another thing is the methods and media of activities that must be formatted in a simple way so that they are easily digested by the people around Seppasuka.

In an effort to build this, there is potential to be developed among the Seppasuka community, in connection with the geographical conditions of these kelurahan close to the Semarang State University, especially in this case the character hermitage which is in the Political and Citizenship Education department. Efforts to create synergy between the Seppasuka community and the character hermitage, in building an understanding and appreciation of the values of Pancasila, are very possible. The existence of the character hermitage in addition to the need for lecture development activities, PPKn teacher development activities in schools, must also provide benefits to the village community around campus, especially in fostering Pancasila values effectively.

The Pancasila Clinic is an alternative solution offered in this study. The Pancasila Clinic in question is an educational activity among rural communities, whose implementation is adjusted to the characteristics of the village community. The activities are carried out in the vicinity of their residence, by taking activities at night, and the content of materials, methods and media is adjusted to their level of thinking. One thing that becomes the standard of the Pancasila Clinic activities is the understanding and appreciation of the community around the Seppasuka village towards the values of Pancasila, so that at the same time the values of Pancasila are implemented in the daily life of the village community.

The Pancasila Clinic is held based on the character hermitage of the Unnes Department 
of Political and Citizenship Education, with the full support of a research team, and in collaboration with community and religious leaders around the Seppasuka community. In its implementation, the research team obtained a lot of important information regarding the implementation of Pancasila values in society and the practice of community, national and state life in the communities around the current area, patemon, pakintelan, sukoreji, and kalisegoro. Information obtained from the community is immediately accepted and accommodated to provide answer solutions that are able to provide solutions or solutions to the problem.

Thus, visually, the implementation of the Pancasila Clinic activities among the Seppasuka community, the researchers described the following:

\section{Pancasila Clinical Development Model}

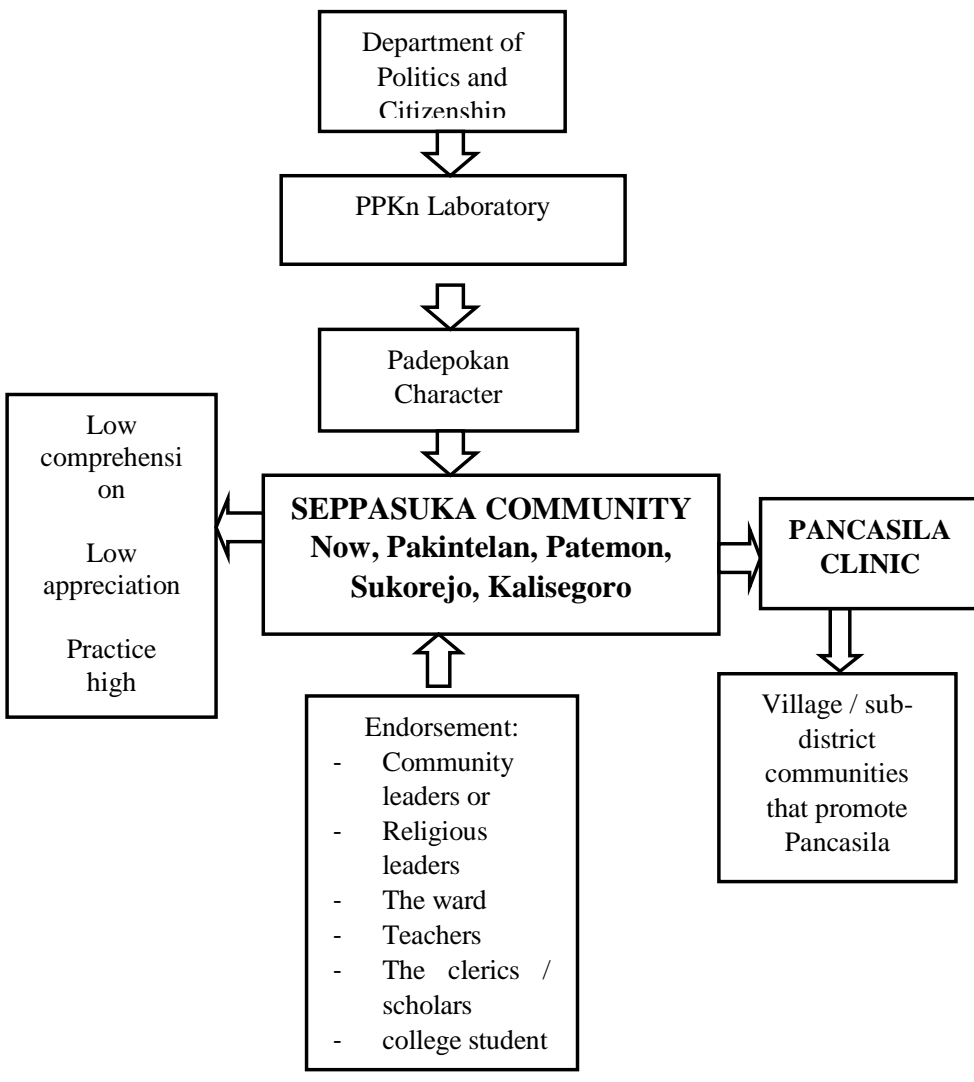

From the chart above, it can be seen that the development of the Pancasila clinic stems from the studies conducted by the Political and Citizenship Department through the Character Padepokan, which are related to the problems that arise regarding the implementation of Pancasila values that occur in the life of society, nation, and having a state in the Sekaran, Pakintelan, Patemon, Sukorejo, and Kalisegoro (Seppasuka) communities such as a low understanding of the values of Pancasila, appreciation of the low Pancasila values of society, and high external influences. Departing from a study conducted in the Department of Politics and Citizenship, the research team utilized the character hermitage as a means of developing the Pancasila clinic which became a solution to the problem solving implementation of the values of Pancasila Sekaran, Pakintelan, Patemon, Sukorejo, and Kalisegoro (Seppasuka). The development of this Pancasila clinic is supported by social capital in society such as religious leaders, community leaders, teachers, scholars, students, and urban villages who still have a high concern for the implementation of Pancasila values in social life, as a nation., and a state in the Sekaran, Pakintelan, Patemon, Sukorejo, and Kalisegoro (Seppasuka) communities.

The Pancasila Clinic aims to help the community solve problems related to the implementation of Pancasila values, accommodate the aspirations and input of the community regarding how the role of Higher Education is to guard and foster the community in implementing and practicing the values of Pancasila, so that it is able to make The people in Sekaran, Pakintelan, Patemon, Sukorejo, and Kalisegoro (Seppasuka) are Pancasila people who are able to understand, live and practice the values of Pancasila in the daily life of the nation, society and state. 


\section{CONCLUSION}

The process of living the values of Pancasila through the Pancasila Clinic will be well realized, when it is done through an intensive communication-interaction process. The process of appreciation occurs when there is dialogue, togetherness, and exemplary among residents to find solutions to problems faced together. Dialogue, togetherness, and exemplary occur when residents observe, explore, analyze, and seek and find alternative solutions to daily problems relating to the practice of Pancasila values. This process is expected to build people with awareness and belief in the truth and the efficacy of Pancasila values. Factors such as people's low understanding of Pancasila values, the community's low appreciation of Pancasila values and external influences such as modernization and high globalization have led to the emergence of the idea of implementing the Pancasila clinic development among the people of Sekaran, Pakintelan, Patemon, Sukorejo, and Kalisegoro (Seppasuka).

The implementation of Pancasila values in the Sekaran, Pakintelan, Patemon, Sukorejo, and Kalisegoro (Seppasuka) communities has been carried out well, the internalization of Pancasila values in the Sekaran, Pakintelan, Patemon, Sukorejo, and Kalisegoro communities, at least in three things, namely the belief in divine values, the spirit of mutual cooperation and the values of deliberation in choosing leaders, both at the RT, RW, and other levels of institutions that support community activities. Even so, there are still problems in implementing Pancasila values in society, especially in facing the changing paradigm of an era that is increasingly open to new things that enter people's lives. The community is still unable to find a solution to how to deal with this paradigm shift which has an impact on the implementation of Pancasila values in society.

The belief in the implementation of the development of the Pancasila clinic can be carried out properly is the support capacity in the form of social capital as well as the presence of religious figures, community leaders, teachers, scholars, students, and urban villages who still have a high concern for the implementation of Pancasila values in social life, nation, and state in the people of Sekaran, Pakintelan, Patemon, Sukorejo, and Kalisegoro (Seppasuka). The Pancasila Clinical Model developed by ilaha researchers by directly visiting the source or location where the community lives and carries out their daily activities. The researcher conducted a dialogue with the community and community leaders about the problems that occurred in society related to the practice of Pancasila values. The next step taken by the research team was to discuss the problems in the hermitage, the character of the politics and citizenship department for a more in-depth study with experts. After conducting an indepth study and obtaining solutions to problems in implementing panasila in the community, the research team returned to the community to present solutions to the problems they experienced. In the future, the development of the Pancasila Clinic will be further intensified by collaborating with the character hermitage and the P3KB study center, Department of Politics and Citizenship, Semarang State University. The Pancasila Clinic will be more intensive in providing Pancasila education to the community around the campus environment, providing solutions to problems faced by the community regarding the implementation of Pancasila values, and together with the community to make Pancasila the life guide for all Indonesians.

The intensity of community discussions within the family, neighborhood, community, and existing community communities continues to be improved. This process is expected to build a society that is aware and sure of the values of Pancasila. 


\section{ACKNOWLEDGMENT}

This work was supported by Universitas Negeri Semarang, Indonesia.

\section{REFERENCES}

[1]Amal, Rahadian,. 2017. Keterampilan Berpikir Kritin Menurut Ennis. Diunduh dari https://www.academia.edu/6523353/Keterampilan_ berpikir_kritis_menurut_ennis. 26/12/2017: 08.30.

[2] Brannen, Julia. 2002. Mixing Methods; Qualitative and Quantitative Research. Illinois: Scott \& Co. Publication.

[3] Davidson. 2002. Moral Innovator and the politics of regeneration: the distinctive role of cultural nationalists in nation building, International journal of comparative sociology. http://cos.sagepub.com (23 Oktober 2016).

[4] Ellemers, J.E. 2007. The Revolt of the Netherlands The Part played by religion in the process of nationbuilding, Social Compass. http://scp.sagepub.com (23 Oktober 2008).

[5] Latif, Yudi. 2015. Negara Paripurna: Historisitas, Rasionalitas, dan Aktualitas Pancasila. Jakarta: Gramedia Pustaka Utama.

[6] ---ota 2017. Mata Air Keteladanan, Pancasila dalam Perbuatan. Jakarta: Mizan.

[7] Masrukhi. 2014. Nilai dan Moral, sebuah Diskursus. Yogyakarta : Penerbit K Media.

[8] Moleong, 2000, Metode Penelitian Kualitatif. Jakarta : Penerbit Gramedia.

[9] Nucci, Larry P. dan Darcia Narvaez, 2016. Handbook Pendidikan Moral dan Karakter. Terjemahan oleh Imam Baihaqie dan Derta Sri Widowatie. Bandung: Nusa Media. 